\title{
Job Satisfaction of Faculty Members in Private Universities -In Context of Bangladesh
}

\author{
Taskina Ali (Corresponding author) \\ Senior Lecturer, Department of Business Administration, East West University \\ 43, Mohakahli, Dhaka Bangladesh \\ Tel: 88-0171-504-0592Ｅ-mail: taskina.ali@gmail.com \\ Ireen Akhter \\ Assistant Professor, Department of Business Administration., \\ Jahangirnagar University, Savar, Dhaka, Bangladesh. \\ Tel: 88-0171-134-5773 E-mail: ireen_sm@yahoo.com
}

\begin{abstract}
Job satisfaction is one of the most widely discussed issues in organizational behavior, personnel and human resource management and organizational management. As teaching does require a great deal of thoroughness and commitment, so in teaching it is more important to have mental commitment and loyalty than physical presence. In this study the researchers investigated the present level of job satisfaction among the faculty members of private universities of tertiary level in Bangladesh. Based on a survey, it attempts to gain insights into the satisfaction levels from the perspective of the private university teachers. The study concluded with the facts that faculty members are overall satisfied with their present condition, except the factors like- training facilities, and some physical facilities and distribution of courses. Further it has been found that there is no significant difference between male and female faculty members regarding job satisfaction. As the job itself is not gender bias by nature so it does not play a crucial role for female faculty members while working under masculine culture. The researchers summed up with view that universities may give more attention to motivate and maintain these human resources to make them more contented and to make the most of their effort by ensuring overall excellence of organization.
\end{abstract}

Keywords: Job satisfaction, Faculty members, Tertiary level, Job descriptive index.

\section{Background of the Study}

Around the globe it is an established fact that a person with a high level of job satisfaction has a positive attitude towards the job, while a person who is dissatisfied with the job has a negative attitude. When people speak of employee attitude, they usually are referring to job satisfaction (Stephen P. Robbins, Mary Coulter, 2004). Job satisfaction has been defined by Locke (1976), as “. . . a pleasurable or positive emotional state resulting from the appraisal of one's job or job experiences". Edwin A. Locke's Range of Affect Theory (1976) is arguably the most famous job satisfaction model. The main premise of this theory is that satisfaction is determined by a discrepancy between what one wants in a job and what one has in a job. An early form of job satisfaction theory held that all elements of one's work environment contributed in additive fashion to the total job satisfaction which one realized. Job satisfaction has been considered as a component of organizational commitment. (Kovach, 1977), Spector (1997) believes that job satisfaction "can be considered as a global feeling about the job or as a related constellation of attitudes about various aspects or facets of the job". There is some evidence in the literature that state moods are related to overall job satisfaction (Roberson L., 1989). Positive and negative emotions were also found to be significantly related to overall job satisfaction (Fisher D., 2000). Numerous studies have shown that dissatisfied employees are more likely to quit their jobs or be absent than satisfied employees (e.g., Hackett \& Guion, 1985; Hulin, Roznowski, \& Hachiya, 1985; Kohler \& Mathieu, 1993).

Extensive study has shown that job satisfaction has a direct impact on the performance of employees in different levels of profession. It is related to employee motivation and performance (Ostroff, 1992). For any company or enterprise this job satisfaction of total workforce plays a vital role and with a group of satisfied worker institutions can successfully implement their plan. Job satisfaction is one of the most widely discussed issues in organizational behavior, personnel and human resource management and organizational management. In simple terms, it is the extent to which one feels good about the job. Job satisfaction is in regard to one's feelings or state of mind regarding to the nature of their work (Shamima Tasnim, 2006).

According to the human behavior, people are more interested to work in those companies and service organizations from where they get mental satisfaction. Study found that politics-free work environment is significantly correlated to 
job satisfaction of employees (Pathik and Pestonjee 1997). The work situation also matters in terms of job satisfaction and organization impact. Research studies across many years, organizations, and types of jobs show that when employees are asked to evaluate different facets of their job such as supervision, pay, promotion opportunities, coworkers, and so forth, the nature of the work itself generally emerges as the most important job facet (Judge \& Church, 2000; Jurgensen, 1978).

The source of this job satisfaction not only arises from the job but also from the other factors like- work environment (both physical and social), relationship with supervisors \& peers, corporate culture, managerial style. These factors have different impact on different people and in practical world it is an established fact that gender differences also influence the job satisfaction level. Herzberg, Mausner, Peterson, and Capwell (1957) observe that "the comparison of job attitudes between men and women is of less interest than a study of the effects of the societal roles of men and women on their attitudes toward jobs." They suggested that the job attitudes of the sexes depend essentially on the same determinants, but that the determinants vary in the intensity of their effects. Hulin and Smith (1964) maintain that if sources of correlated bias, such as pay, job level, promotional opportunities, and societal norms, are held constant or partially out, sex differences in job satisfaction will disappear, and they (Hulin and Smith, 1965) caution investigators "to draw distinctions between male and female."

Herzberg et al (1957) reported that the job adjustment of female workers is often made more difficult because they must divide their interests and attention between the working world and their traditional role and that the social and psychological pressures toward marriage complicate the job attitudes of the unmarried female. They take up their jobs primarily for their livelihood, which is conditioned by job satisfaction (Locke, 1976). On the other hand, Campbell (1976) reported that single men are less job satisfied than married men, but that no such difference exists for females. Lacy, Bokemeier and Shepard (1983) find no differences in the consequences of gender-specific childhood socialization for job satisfaction. Nor do they find that a wide range of job characteristics differentially affect the work attitudes of men and women. Where gender differences in work attitudes have been found in the analysis of Murray and Atkinson (1981) that women weight relations with coworkers more heavily and that men weight advancement more heavily, and these differences have been relatively small.

A variety of job characteristics are evaluated to see to what extent men and women differentially value various aspects of their jobs. These characteristics include occupational prestige, earnings, education, job complexity, level of authority exercised, how closely the worker is supervised, job pressure, being held responsible for things outside one's control, how frequently one has to get dirty on the job, being underemployed, workplace size, and level of optimism about one's future at the current job. Relationship with the supervisor is also an important factor influencing the employees. According to Herzberg et al. (1952), it is a hygiene factor that may lead to job dissatisfaction. Employees in organizations are often attracting their supervisors for different reasons. These relationships are called functional and entity relationships (Locke, 1976). Functional relationships between supervisor and subordinate are based on which services can be provided for each other. An employee may be attracted to his or her supervisor to a degree that he or she views the supervisor or helping to attain salient job values (Locke, 1970). These values are normally related, or are related to the rewards the employee can accrue for task performance. Again, welfare (wellness) programs including benefits, bonus, overtime, transport allowance, medical allowance, etc., have positive relationships with job satisfaction of employees (Bonner 1997).

While the dimensions of job satisfaction appear fairly clear, the causal agents of satisfaction are far less so. Certainly, variables such as opportunity to participate in decision making (Daly, McCroskey, \& Falchion, 1976, Vroom, 1964), job enlargement (Argyris, 1964), job enrichment (Herzberg, 1966), working conditions (Barnowe 1972), and the individual's perceptions of his or her success and the internal-external feedback one receives from his or her performance (Hackman \& Lawler, 1971), all have some effect.

These and related measures of job and organizational characteristics have a long history of use in the literature on job satisfaction and have been consistently identified as major determinants of job satisfaction (Parnes, Shea, Spitz, and Zeller 1970; Quinn, Staines, and McCullough 1974). Actually, Job satisfaction results from the balancing and summation of many specific likes and dislikes of employees experienced over a period of time through gaining more and more information about the workplace (Huang 1999; Ganguli 1994).

A popular measure of job satisfaction- the Job Descriptive Index (JDI) - measure satisfaction in terms of five aspects of a person's job: pay, promotion, supervision, the work itself, and co-workers (Hellriegel and Woodman, 1995). There is even some evidence that job satisfaction positively influence organizational citizenship behavior (Organ and Ryan, 1995). In academic institution, Clarke and Keating (1995) discovered that interaction with students was the most satisfying aspect for teachers, while lack of administrative support was the least satisfying aspect. Perkins (1991) also found that teachers are most satisfied with their co-workers and least satisfied with monetary aspects of teaching. Universities that have overall salary levels that are externally competitive are more likely to have faculty members that are more satisfied with their jobs and with their pay (Terpstra and Honoree, 2004). This was also confirmed by Faruqui 
and Shoma, (2005) that the most dissatisfactory issues for faculty are salary structure and untimely payment, students' quality, and the prolonged working hours.

Recently in Bangladesh private universities are greatly contributing to the higher level education because it was felt by all that the existing public universities are not enough to meet the growing demand of our students. They are providing international standard course curriculum, which helps the domestic students to study at their own home relatively at a lower cost. But they can avail the international standard degrees. In these private universities a large number of male/ female faculty members are rendering their services who have national as well as international higher degrees and also having high experiences. A career in education is challenging and its impact is important. As teaching does require a great deal of thoroughness and commitment, so in teaching it is more important to have mental commitment and loyalty than physical presence (Akhter, Muniruddin \& Sogra 2008). But if these faculty members are not satisfied with their profession they will not be able to increase their performance and thus will not contribute to education sector of Bangladesh. Therefore, the focus of this study is to reveal the level of job satisfaction of faculty members in private universities of Bangladesh.

\section{Research Objectives:}

The purpose of this study is to find out the perceived job satisfaction of faculty members of different private universities of Bangladesh. The study has identified:

- The general profile of the faculty members.

- The present level of job satisfaction of faculty members of tertiary level.

- The comparison of the satisfaction level between male and female faculty members in various private universities of Bangladesh.

- Weather the masculine cultures causes any dissatisfaction among female faculty members.

\section{Research Methods:}

\subsection{Sources of Data:}

Comprehensive research work has been conducted to achieve the aforesaid objectives of the study. Both primary and secondary data have been used for the purpose of this study. To collect primary data a structured questionnaire was designed in the light of the objectives of the study. Faculty members from different levels of different private universities were requested to fill the questionnaire. Secondary data were collected from available books, publications, research studies, journals, websites and articles on job satisfaction of employees of different professions, including academic institutions.

\subsection{Sample Size and Location:}

A list of private universities in Bangladesh has been taken from the University Grant Commissions (UGC). According to that list total 51 private universities (till date 23/07/09) are currently operating in Bangladesh. The sample of the study covers the faculty members from different private universities of Bangladesh. A sample of $120[\mathrm{~N}=120]$ faculty members where 60 male and 60 female (50\% male and 50\% female) selected purposively from different levels from 10 private universities (among 51 private universities) of different areas (Annexure-A) of Dhaka city. The researchers have chosen these areas for survey, as most of the private universities are situated mainly in those areas of Bangladesh. However, most of the private universities in other districts are branches of universities located in Dhaka city. Here the researchers would like to mention the reasons behind selecting private universities instead of public universities as public universities salary structure, HR policies are same but it varies with private universities. Other reasons private universities are operating in Bangladesh for almost last 17 to 18 years. So now it is in the growth stage and we can analyze its condition. At the same time researchers did not go for departmental analysis in respective universities because all the private universities do not have similar departments.

\subsection{Questionnaire Design:}

A structured, closed- ended questionnaire (Annexure-C) was given to respondents for collecting their opinion regarding job satisfaction. The respondents were also asked about their sex, total years of education, academic rank, and total years of work experience.

\subsection{Techniques Used:}

In terms of scaling method, a five point likert scale ( 5 for highly satisfied, 4 for satisfied, 3 for neither satisfied nor dissatisfied, 2 for dissatisfied and 1 for highly dissatisfied) has been used. For analysis of data, Microsoft Excel has been used. To entry data, coding option has been used at the initial stage. Both parametric and non-parametric statistical tools were used to derive a meaningful conclusion from the empirical data. In addition, basic statistical techniques of different measures of central tendency have been used in analyzing the data. 


\section{Study Findings:}

The population of the study was all faculty members of business school of private universities of Bangladesh. And the sample was consisted of faculty members of different levels (Professor- $0.83 \%$, Associate Professor- $1.67 \%$, Assistant Professor-19.16\%, Senior Lecturer-5\%, and Lecturer-73.33\%). Majority of the faculty members are young (between 25 yrs to 40 yrs.) and only $14.16 \%$ are more than 40 years of age. From this study it was found that only 11.67 percent of the faculty members have higher degrees like $\mathrm{PhD}$ and among them male are dominant (Annexure-B).

Table-1 lists the statements and average scores received for each statement for both male and female faculty members. The range of the average scores for the male respondents for twenty statements were between 2.67 to 4.3 and the average scores for the female respondents for twenty statements were between 2.07 to 4.42 . Only in one cases (statement- S-15, "Faculty members are satisfied with present training system as well as training facilities") the mean scores (2.97) of male were equal to female faculty members. In case of four statements (S-2, S-3, S-14, S-18) the mean scores of male were less than female faculty members. Similarly in case of the rest 15 statements, the mean scores of male were higher than female faculty members. The range of the average scores for both male and female respondents for twenty statements was between 2.37 to 4.36 . It is very interesting that both respondents are highly satisfied with interpersonal relationship with colleagues (mean score for male is 4.3 , mean score for female is 4.42 , and average mean score for both is 4.36) and highly dissatisfied with present placement and course distribution (mean score for male is 2.67 , mean score for female is 2.07 , and average mean score for both is 2.37). But the average mean score for both male and female is 3.29 , which is somehow alarming for this sector.

Table-2 lists the comparative ranking based on the average score of the each group. Only five cases, (SA-13, SA-12, SA-10, SA-9 and SA-16) both groups placed $\left(1^{\text {st }}, 2^{\text {nd }}, 3^{\text {rd }}, 4^{\text {th }}\right.$ and $20^{\text {th }}$ respectively) same ranking. Both groups are satisfied in same way with interpersonal relationship with their colleagues (ranked $1^{\text {st }}$ ), with family support (ranked $2^{\text {nd }}$ ), teachers and students relationship (ranked $3^{\text {rd }}$ ) and location of the universities (ranked $4^{\text {th }}$ ). Again both groups are most dissatisfied in same way with present placement and course distribution (ranked $20^{\text {th }}$ ). For rest of the 15 statements ranking varied for both male and female. These disparities suggest that male and female faculty members have different level of job satisfaction towards various factors.

Participation of women in different jobs in Bangladesh is increasing. Open market policy of the government and increasing educational trend among women has bought them to come forward to take this challenge of socioeconomic development. (Nazrul, 2000). The researcher designed five extra questions only for female respondents to find out the correlation (r) between male and female to show whether any masculine culture works while doing job in the same profession and almost from same background. In table-3, it is shown that for all statements (statements 21 to statements 25) the relationship between gender and other factors are strong. Though the female faculty members have less opportunity to work as of male faculty members does (mean 3.05) but at the same time female members are getting recognition of performance by their male counterparts (mean 3.33). Female faculty members do think that tough jobs are always given to male faculty members (mean 2.62) and as woman they are being kept aside in decision making (mean 2.22). Also, female faculty members do not think that male teachers show rigidity in opinion while female teacher's opinion is much better (mean 1.97). So the researcher can easily end up in to a decision that there is not great difference between male and female faculty members in their satisfaction level in the environmental and social context.

\section{Conclusion and Recommendations:}

- This study mainly focused on satisfaction level of faculty members of different private universities. From this study it has been found that faculty members are satisfied in some areas like interpersonal skills, but at the same time dissatisfied in other areas like salaries, personal room, computer facilities, office room, wash room facilities, etc.

- The old adage "you get what you pay for" tends to be true when it comes to staff members. If individuals believe they are not compensated well, they will be unhappy. Normally this sector (universities) in our country provides less compensation compare to other sectors. Universities may offer comparable salaries and benefits to retain compatible faculty members.

- The environment in which people work has a tremendous effect on their level of pride for themselves and for the work they are doing. Even a nice chair can make a world of difference to an individual's psyche. Universities should look more to provide facilities like personal room with modern computer facilities to avoid overcrowding and allow them to use their own personal space so that they can give more time for their research work besides their regular class. They should also provide clean washroom facilities.

- Faculties are also dissatisfied with training facilities. Universities must also work to develop their faculty members. Training and development enable employees to perform their present jobs effectively and to prepare for future jobs.

- Faculty members are most dissatisfied with course allocation as they claim that sometimes it creates extra burden for them. Universities are not utilizing their expertise; rather courses are distributed depending on demand. In this case, it may not be possible to ignore the demand of any course, but faculty members may be informed earlier to take necessary 
preparation before starting the semester.

- In this it was also studied weather gender plays any discrimination between male and female faculty members. As the nature of the job itself is not that much discriminatory, gender does not plays any critical role here. Female faculty members thought that they have same opportunity to work as of male teacher does and they are also get recognition from their male counterpart for their performance. But the mean scores are not that much satisfactory. So universities may give more room for female faculty members. As this is the place to sell knowledge and expertise, female faculty members can make more contribution if they are utilize properly.

- At the end of the research the researchers may summed up with view that universities may give more attention to motivate and maintain these human resources to make them more contented and to make the most of their effort by ensuring overall excellence of organization.

Insert Table 1, Table 2, Table 3 Here

\section{References}

Akhter I, Muniruddin G, and Sogra K. J., (2008)"A Trend Analysis of Faculty Turnover at the Private universities in BangLAdesh: A Business School Perspective” Journal of Business Studies, Vol. IV, No.1.

Argyris, C. (1964) Integrating the Individual and the Organization. New York: Wiley.

Barnowe, J.T. (1972) The relative importance of job facets as indicated by an empirically derived model of job satisfaction. Survey Research Center, University of Michigan, Ann Arbor.

Bonner, m. (1997). Stages of Change, Job Satisfaction, Weight, and Activity at Two Work-Site Wellness Programs, Doctoral Dissertation, The University of Southern Mississippi, USA.

Brief, (1998) cited in Weiss, H. M. (2002). Deconstructing job satisfaction: separating evaluations, beliefs and affective experiences. Human Resource Management Review, 12, 173-194, p. 174

Clarke, R., and Keating, W. F. (1995).A fresh look at teacher job satisfaction. ERIC document Reproduction Service No. ED 391-795.

Campbell, A., P. E. Converse, and W. L. Rodgers. (1976) TIte Qualit?: of Arnericarz Life(New York: Russell Sage,.

Daly, J.A., McCroskey, J.C., \& Falcione, R.L. (1976) Communication apprehension, supervisor communication receptivity and satisfaction with superiors. Paper presented at the annual meeting of the Eastern Communication Association, Philadelphia.

Fisher D. (2000).Mood and Emotions while Working: missing pieces of job satisfaction? Journal of Organizational Behavior 21, 185 \pm 202

Faruqui, G.A and Islam, S. (2005) Evaluation of faculty's job satisfaction in private universities, Journal of Business Studies, 1(2):67-82.

Ganguli, H.C. (1994). Job Satisfaction Scales for Effective Management: Manual for Managers and Social Scientists, Concept Publishing Company, New Delhi.

Hackett, R. D., \& Guion, R. M. (1985). A re-evaluation of the absenteeism-job satisfaction relationship. Organizational Behavior and Human Decision Processes, 35, 340-381.

Hackman, J.R., \& Lawler, E.E. (1971) Employee reactions to job characteristics. (Monograph) Journal of Applied Psychology, 55, 259-286.

Hellriegel, D., Slocum, Jr. W. J., and Woodman, W.R (1995) Organizational Behavior. St. Paul: West Publishing Company.

Herzberg, F., B. Mausner, R. 0. Peterson, and D. F. Capwell (1957). Job Attitudes: Review of Research and Opinion (Pittsburgh, Pa.: Psychological Service of Pittsburgh.

Herzberg, F. (1966.)Work and the Nature of Man. Cleveland: World.

Herzberg, F., Mausner, B. and Synderman, B., (1952). The Motivation to Work, John Willy and Sons, New York.

Huang, H.J. (1999). “Job Rotation from the Employees' Point of View”, Research and Practice in Human Resource Management, 7(1):76.

Hulin. C. L., and P. C. Smith. (1964) "Sex Differences in Job Satisfaction," Journal of Applied Psychology, Vol. 48. $88-92$.

Hulin, C. L., and P. C. Smith, (1965) "A Linear Model of Job Satisfaction," Journal of Applied Psychology, Vol. 49, 209-216. 
Hulin, C. L., Roznowski, M., \& Hachiya, D. (1985). Alternative opportunities and withdrawal decisions: Empirical and theoretical discrepancies and integration. Psychological Bulletin, 97, 233-250.

Judge, T. A., \& Church, A. H. (2000). Job satisfaction: Research and practice. In C. L. Cooper \& E. A. Locke (Eds.), Industrial and organizational psychology: Linking theory with practice (pp. 166-198). Oxford, UK: Blackwell.

Jurgensen, C. E. (1978). Job preferences (What makes a job good or bad?). Journal of Applied Psychology, 63, 267-276.

Kohler, S. S. \& Mathieu, J. E. (1993). An examination of the relationship between affective reactions, work perceptions, individual resource characteristics, and multiple absence criteria. Journal of Organizational Behavior, 14, 515-530.

Kovach, K.A. (1977). Organizational size, job satisfaction, absenteeism, and turnover. Washington, D.C. University Press of America

Lacy, William B., Janet L. Bokemeier, and Jon M. Shepard. (1983). "Job Attribute Preferences and Work Commitment of Men and Women in the United States." Personnel Psychology 36 315-329.

Locke, (1976), A. P., \& Weiss, H. M. (2001). Organizational behavior: Affect in the Workplace. Annual Review of Psychology, 53, 279-307, p. 282.

Locke, E.A. (1965) The Relationship of Task Success to Task Liking and Satisfaction. Journal of Applied Psychology, 49, 379-385.

Locke, E.A. (1970). Job satisfaction and job performance: A theoretical analysis. Organizational Behavior and Human Performance, 5, 484-500 (b).

Locke. E.A. (1970) The supervisor as "motivator": His influence on employee performance and satisfaction. In B.M. Bass, R. Cooper. and J.A. Hass (Eds.), Managing for accomplishment. Lexington: 57-67.

Murray, Michael A., and Tom Atkinson. (1981). "Gender Differences in Correlates of Job Satisfaction." Canadian Journal of Behavioral Science 13,1 : 44-52.

Nazrul Islam, Gour Chandra Saha, Feroz (2000) Ahmed, An evaluation of job satisfaction of women employees in commercial banks in Bangladesh, Journal of Business Administration, Vol. 26, No. 3 \& 4, July \& October, 2000), Institute of Business Administration, University of Dhaka.

Organ, D.W. and Ryan, K. (1995) A meta-analytic review of attitudinal and dispositional predictors of organizational citizenship behavior. Personnel Psychology. 48: 775-803.

Ostroff, C. (1992).The relationship between satisfaction, attitudes, and performance: An organizational level analysis. Journal of Applied Psychology, 77: 963-974.

Parnes, Shea, Spitz, and Zeller (1970). Gender Differences in Job Satisfaction. The Sociological Quarterly; Volume 30, Issue 3. Page 385-399.

Pathik,R.D. and Pestonjee,D. D. (1997). Organizational Politics Orientation as Related to Job Satisfaction, Job Involvement and Job Anxiety among Research and Development Personnel. South Asian Journal of Management, pp. 39-44.

Perkins, C. M. (1991) A study to investigate experienced teachers Job satisfaction and the teachers' perception of their principals' leadership style Doctoral Dissertation, The University of North Carolina at Chapel Hill. Dissertation abstracts International, 52, A4171.

Quinn, Robert, G. Staines, and B.C. McCullough. (1974). Job Satisfaction: Is There a Trend? Washington, D.C.: U.S. Government Printing Office.

Roberson L.(1989). Job attitude organization: an exploratory study. Journal of Applied Social Psychology 19: $717 \pm 727$.

Shamima Tasnim, (Spring 2006).Job Satisfaction among Female Teachers: A study on primary schools in Bangladesh. M.Phil. The University of Bergen, Bergen, Norway.

Spector, P.E. (1997) Job Satisfaction: Application, assessment, cause and consequences. Thousand Oaks, CA: Sage Publications, Inc.

Stephen P. Robbins, Mary Coulter, (January 14, 2004). Management, Eight edition, Pearson Prentice Hall.

Terpstra, David E, Honoree, Andre L (2004) Job satisfaction and pay satisfaction levels of university faculty by discipline type and by geographic region, Education, Accessed on 15.01.2008.

Vroom. V.H. (1964).Work and Motivation. New York: Wiley.

. $<$ http://findarticles.com/p/articles/mi_qa3673/is_200404/ai_n9345191> www.ugc.gov.bd/private_universities. 
Table 1. Job Satisfaction Level of Faculty Members

\begin{tabular}{|c|c|c|c|c|c|}
\hline & Job Satisfaction Level of Faculty Members & $\begin{array}{l}\text { M Score } \\
\text { Mean }\end{array}$ & $\begin{array}{c}\text { F Score } \\
\text { Mean }\end{array}$ & $\begin{array}{c}\text { Mean } \\
\text { Difference }\end{array}$ & $\begin{array}{c}\text { Average } \\
\text { Score Mean }\end{array}$ \\
\hline S-1 & $\begin{array}{l}\text { Faculty members are satisfied with the present salary } \\
\text { structure }\end{array}$ & 3.17 & 3.12 & 0.05 & 3.15 \\
\hline S-2 & $\begin{array}{l}\text { Faculty members are satisfied with present academic } \\
\text { qualification }\end{array}$ & 3.37 & 3.60 & -0.23 & 3.48 \\
\hline S-3 & $\begin{array}{l}\text { Faculty members are satisfied with present social status } \\
\text { as a teachers }\end{array}$ & 3.30 & 3.47 & -0.17 & 3.38 \\
\hline S-4 & Faculty members are satisfied with classroom & 3.37 & 2.95 & 0.42 & 3.16 \\
\hline S-5 & Faculty members are satisfied with office room & 3.23 & 2.65 & 0.58 & 2.94 \\
\hline S-6 & Faculty members are satisfied with personal room & 3.10 & 2.37 & 0.73 & 2.73 \\
\hline S-7 & Faculty members are satisfied computer facilities & 3.00 & 2.87 & 0.13 & 2.93 \\
\hline S-8 & Faculty members are satisfied with washroom facilities & 3.27 & 2.57 & 0.70 & 2.92 \\
\hline S-9 & $\begin{array}{l}\text { Faculty members are satisfied with well communication } \\
\text { and location of the university }\end{array}$ & 3.90 & 3.82 & 0.08 & 3.86 \\
\hline S-10 & $\begin{array}{l}\text { Faculty members are satisfied with teacher and student } \\
\text { relationship }\end{array}$ & 4.10 & 3.88 & 0.22 & 3.99 \\
\hline S-11 & $\begin{array}{l}\text { Faculty members are satisfied with university managing } \\
\text { committee }\end{array}$ & 3.50 & 3.40 & 0.10 & 3.45 \\
\hline S-12 & Faculty members are satisfied with family support & 4.17 & 3.93 & 0.23 & 4.05 \\
\hline S-13 & $\begin{array}{l}\text { Faculty members are satisfied with interpersonal } \\
\text { relationship with colleagues }\end{array}$ & 4.30 & 4.42 & -0.12 & 4.36 \\
\hline S-14 & $\begin{array}{l}\text { Faculty members are satisfied with career prospect of } \\
\text { this job }\end{array}$ & 3.27 & 3.28 & -0.02 & 3.28 \\
\hline S-15 & $\begin{array}{l}\text { Faculty members are satisfied with present training } \\
\text { system as well as training facilities }\end{array}$ & 2.97 & 2.97 & 0.00 & 2.97 \\
\hline S-16 & $\begin{array}{l}\text { Faculty members are satisfied with present placement } \\
\text { and course distribution. }\end{array}$ & 2.67 & 2.07 & 0.60 & 2.37 \\
\hline S-17 & $\begin{array}{l}\text { Faculty members are satisfied with current supervision } \\
\text { style (by dept. chairman ) }\end{array}$ & 3.77 & 3.32 & 0.45 & 3.54 \\
\hline S-18 & $\begin{array}{l}\text { Faculty members are satisfied with permanency of the } \\
\text { job }\end{array}$ & 2.73 & 3.28 & 0.55 & 3.01 \\
\hline S-19 & $\begin{array}{l}\text { Faculty members are satisfied with power distance } \\
\text { between faculty members and central administration. }\end{array}$ & 3.03 & 3.00 & 0.03 & 3.02 \\
\hline \multirow[t]{2}{*}{ S-20 } & $\begin{array}{l}\text { Faculty members are satisfied with power distance } \\
\text { between chairman and central administration }\end{array}$ & 3.30 & 3.05 & 0.25 & 3.18 \\
\hline & AVERAGE & 3.38 & 3.2 & 0.18 & 3.29 \\
\hline
\end{tabular}

Notations: $\mathrm{M}=$ Male faculty members, $\mathrm{F}=$ Female faculty members. 
Table 2. Comparative Ranking of Statements (strongest to weakest)

\begin{tabular}{|c|c|c|c|}
\hline & Job Satisfaction Level of Faculty Members & $\begin{array}{c}\text { Average } \\
\text { Male }(50 \%)\end{array}$ & $\begin{array}{c}\text { Average } \\
\text { Female }(50 \%)\end{array}$ \\
\hline S-13 & $\begin{array}{l}\text { Faculty members are satisfied with interpersonal relationship with } \\
\text { colleagues }\end{array}$ & $1^{\text {st }}$ & 1 st \\
\hline S- 12 & Faculty members are satisfied with family support & $2^{\text {nd }}$ & 2nd \\
\hline S-10 & Faculty members are satisfied with teacher and student relationship & $3^{\text {rd }}$ & $3 \mathrm{rd}$ \\
\hline S- 9 & $\begin{array}{l}\text { Faculty members are satisfied with well communication and location of } \\
\text { the university }\end{array}$ & $4^{\text {th }}$ & 4th \\
\hline S-17 & $\begin{array}{l}\text { Faculty members are satisfied with current supervision style ( by dept. } \\
\text { chairman ) }\end{array}$ & $5^{\text {th }}$ & $8^{\text {th }}$ \\
\hline S-11 & Faculty members are satisfied with university managing committee & $6^{\text {th }}$ & $7^{\text {th }}$ \\
\hline $\mathrm{S}-2$ & Faculty members are satisfied with present academic qualification & $7^{\text {th }}$ & $5^{\text {th }}$ \\
\hline S- 4 & Faculty members are satisfied with classroom & $8^{\text {th }}$ & $15^{\text {th }}$ \\
\hline S-20 & $\begin{array}{l}\text { Faculty members are satisfied with power distance between chairman and } \\
\text { central administration }\end{array}$ & $9^{\text {th }}$ & $12^{\text {th }}$ \\
\hline $\mathrm{S}-3$ & Faculty members are satisfied with present social status as a teachers & $10^{\text {th }}$ & $6^{\text {th }}$ \\
\hline S- 8 & Faculty members are satisfied with washroom facilities & $11^{\text {th }}$ & $18^{\text {th }}$ \\
\hline S-14 & Faculty members are satisfied with career prospect of this job & $12^{\text {th }}$ & $10^{\text {th }}$ \\
\hline S-5 & Faculty members are satisfied with office room & $13^{\text {th }}$ & $17^{\text {th }}$ \\
\hline S-1 & Faculty members are satisfied with the present salary structure & $14^{\text {th }}$ & $11^{\text {th }}$ \\
\hline S- 6 & Faculty members are satisfied with personal room & $15^{\text {th }}$ & $19^{\text {th }}$ \\
\hline S-19 & $\begin{array}{l}\text { Faculty members are satisfied with power distance between faculty } \\
\text { members and central administration. }\end{array}$ & $16^{\text {th }}$ & $13^{\text {th }}$ \\
\hline S-7 & Faculty members are satisfied computer facilities. & $17^{\text {th }}$ & $16^{\text {th }}$ \\
\hline S-15 & $\begin{array}{l}\text { Faculty members are satisfied with present training system as well as } \\
\text { training facilities. }\end{array}$ & $18^{\text {th }}$ & $14^{\text {th }}$ \\
\hline S-18 & Faculty members are satisfied with permanency of the job. & $19^{\text {th }}$ & $9^{\text {th }}$ \\
\hline S-16 & $\begin{array}{l}\text { Faculty members are satisfied with present placement and course } \\
\text { distribution. }\end{array}$ & $20^{\text {th }}$ & 20th \\
\hline
\end{tabular}

Table 3. Job Satisfaction Level of Female Faculty Members.

\begin{tabular}{|c|l|c|c|c|}
\hline & Job Satisfaction Level of Female Faculty Members & $\begin{array}{c}\text { F Score } \\
\text { Mean }\end{array}$ & $\begin{array}{c}\text { Mean } \\
\text { Difference }\end{array}$ & r-value \\
\hline S-21 & Female faculty has same opportunity to work as of male teacher does & 3.05 & 0.41 & .807 \\
\hline S-22 & $\begin{array}{l}\text { Female faculty members get recognition from their male counterpart } \\
\text { for their performance }\end{array}$ & 3.33 & 0.70 & .854 \\
\hline S-23 & $\begin{array}{l}\text { The rigorous or the tough jobs are always assigned to the male } \\
\text { teacher }\end{array}$ & 2.62 & -0.02 & .835 \\
\hline S-24 & $\begin{array}{l}\text { Female faculty members are kept aside in important decision making } \\
\text { because of being an woman }\end{array}$ & 2.22 & -0.42 & .829 \\
\hline S-25 & $\begin{array}{l}\text { Male teachers show rigidity in opinion while female teacher's } \\
\text { opinion is much better }\end{array}$ & 1.97 & -0.67 & .754 \\
\hline
\end{tabular}

Note: Average Score Mean (All) is 2.637

\section{Appendix}

\section{Appendix-A: Samples in Terms of Institutions and Gender}

\begin{tabular}{|c|c|c|c|c|c|}
\hline Areas Covered & No. & Name of Institution & $\begin{array}{c}\text { No. of } \\
\text { Samples }\end{array}$ & Male & Female \\
\hline \multirow{5}{*}{$\begin{array}{l}\text { A. } \\
\text { Uttara, Banani, } \\
\& \\
\text { Mohakhali }\end{array}$} & 1 & North South University & 12 & 6 & 6 \\
\hline & 2 & East West University & 12 & 6 & 6 \\
\hline & 3 & BRAC University & 12 & 6 & 6 \\
\hline & 4 & South East University & 12 & 6 & 6 \\
\hline & 5 & Asian University of Bangladesh & 12 & 6 & 6 \\
\hline \multirow{6}{*}{$\begin{array}{l}\text { B. } \\
\text { Mirpur, } \\
\text { Mohammadpur } \\
\& \\
\text { Dhanmondi }\end{array}$} & 6 & University of Asia Pacific & 12 & 6 & 6 \\
\hline & 7 & Stamford University & 12 & 6 & 6 \\
\hline & 8 & World University of Bangladesh & 12 & 6 & 6 \\
\hline & 9 & Daffodil International University & 12 & 6 & 6 \\
\hline & 10 & Northern University of Bangladesh & 12 & 6 & 6 \\
\hline & & Total & $120(100 \%)$ & $60(50 \%)$ & $60(50 \%)$ \\
\hline
\end{tabular}


Source: primary source

Appendix -B: Features of the Respondents

\begin{tabular}{|c|c|c|c|c|c|c|c|c|}
\hline \multicolumn{2}{|c|}{ Characteristic } & \multicolumn{2}{|c|}{ Male } & \multicolumn{2}{|c|}{ Female } & \multicolumn{2}{|c|}{ All } & \multirow{2}{*}{$\begin{array}{c}\text { All } \\
\%\end{array}$} \\
\hline \multirow{2}{*}{ Sample } & \multirow{2}{*}{ Respondents } & $\mathrm{M}$ & $\%$ & $\mathrm{~F}$ & $\%$ & All & $\%$ & \\
\hline & & 60 & 50 & 60 & 50 & 120 & 100 & 100 \\
\hline \multirow{3}{*}{$\begin{array}{c}\text { Years of } \\
\text { schooling }\end{array}$} & Up to 17 years & 32 & 26.67 & 32 & 28.33 & 66 & 55 & \multirow{3}{*}{100} \\
\hline & $17-18$ years & 18 & 15 & 22 & 18.33 & 40 & 33.33 & \\
\hline & 19 years and above & 10 & 8.33 & 4 & 3.33 & 14 & 11.67 & \\
\hline \multirow{3}{*}{$\begin{array}{c}\text { Years of } \\
\text { Work } \\
\text { Experience }\end{array}$} & Less than 5 & 26 & 43.33 & 12 & 20 & 38 & 31.67 & \multirow{3}{*}{100} \\
\hline & $5-10$ & 14 & 23.33 & 15 & 25 & 29 & 24.17 & \\
\hline & $10+$ & 20 & 33.33 & 33 & 55 & 53 & 44.17 & \\
\hline \multirow{4}{*}{ Age } & Up to 30 years & 30 & 25 & 23 & 19.17 & 53 & 44.17 & \multirow{4}{*}{100} \\
\hline & $31-40$ years & 26 & 21.67 & 24 & 20 & 50 & 41.67 & \\
\hline & $41-50$ years & 4 & 3.33 & 12 & 10 & 16 & 13.33 & \\
\hline & 50 years and above & 0 & 0 & 1 & 0.83 & 1 & 0.83 & \\
\hline \multirow{5}{*}{ Position } & Lecturer & 50 & 41.67 & 38 & 31.67 & 88 & 73.33 & \multirow{5}{*}{100} \\
\hline & Senior Lecturer & 2 & 1.67 & 4 & 3.33 & 6 & 5 & \\
\hline & Assistant Professor & 8 & 6.67 & 15 & 25 & 23 & 19.16 & \\
\hline & Associate Professor & 0 & 0 & 2 & 1.67 & 2 & 1.67 & \\
\hline & Professor & 0 & 0 & 1 & 0.83 & 1 & 0.83 & \\
\hline
\end{tabular}

Note: M for Male, F for Female

(Source: Questionnaire Survey) 